\title{
Paving Sustainable Development through Generic Green Skills Based on Desk Research
}

\author{
Mohd Zolkifli Abd Hamid, Mohd Safarin Nordin, Yusri Kamin, Aede Hatib Mustamal
}

\begin{abstract}
Generic skills are complementary to technical skills that enable potential employees to secure a place in the job market. A myriad of studies have been conducted on generic skills, and in Malaysia's 'greening' development process, generic green skills have begun to attract many academics and industry players. This paper reviews several articles on generic green skills associated with the green technology industry. Document analysis was conducted to scrutinise initial information extracted from electronic databases viz Google Scholar, ResearchGate, Science Direct, Academia and EBCOHost. The findings showed that endeavours to acquire sustainable development in Malaysia are flourishing and prolific. Government agencies were seen as playing a notable role in strengthening generic green skills among employees in the green technology industry alongside international organisations and regional partners to ensure that development is compatible with maintaining the quality of the environment. In the near future, generic green skills are expected to receive solemn attention from academics and researchers, as well as become key criteria by employers in hiring new employees. Hence, further studies are needed to refine the generic green skills in balancing the development process with environmental sustainability.
\end{abstract}

Index Terms: Generic Green Skill, Environmental Sustainability, Education and Training, Green Technology Industry, Green Jobs

\section{INTRODUCTION}

Efforts to achieve developed country status, as stated in the Malaysian vision 2020 (Nordin, 1994), have long been implemented. However, oversight in the pursuit of rapid development may sometimes result in the neglect of environmental sustainability (Omardin \& Zainul Abidin, 2014). As a result of such greed, many devastations and natural disasters occurred on a large scale. Citing a statement by Rademaekers, Svatikova \& Yearwood (2015), developing countries are not only the most vulnerable to climate change but the effects of environmental degradation are particularly important for them, and can undermine their development.

Despite brisk development, there must be accountability to ensure that it does not affect the lives and well-being of the community in the future (Meerah, Hanim, Othman \& Aziz, 2005).

A pillar to ensure successful development is the availability

Revised Manuscript Received on September 22, 2019.

Mohd Zolkifli Abd Hamid, School of Education, Faculty of Social Sciences and Humanities, University Teknologi Malaysia, Johor, Malaysia.

Mohd Safarin Nordin, School of Education, Faculty of Social Sciences and Humanities, University Teknologi Malaysia, Johor, Malaysia.

Yusri Kamin, School of Education, Faculty of Social Sciences and Humanities, University Teknologi Malaysia, Johor, Malaysia

Aede Hatib Mustamal, School of Education, Faculty of Social Sciences and Humanities, University Teknologi Malaysia, Johor, Malaysia. of competent human resources. At the same time, advanced technology may expedite the development progress. Human resources that contribute to development are those who possess not only high skills, but are also equipped with non-technical or generic skills. In environmentally sustainability development, the concept of 'green' is capturing public attention. Terms such as green economy, green jobs, low-carbon society, green communication, green products and services, sustainable development and generic green skills are starting to garner earnest attention. They are all interconnected in the national development agenda without affecting the quality of the environment. This underscores the timely need to address these issues in sustainable development.

In order to support sustainable development through green technology industrial activities, skilled manpower should be equipped with generic green skills. Generic green skills can be inculcated through education and training. Be it technical skills or non-technical (generic) skills, improving students' ability to practice (skills) and creating a knowledge workforce can be done only through direct experience working in the field or industry (Ratnata, 2015). This refers to education and training as two sides of the same coin. As Watch (2010) summarises, awareness and practice of the importance of environmental preservation and conservation are through education.

\section{DISCUSSION}

\section{Generic Skill}

Skills are key to productivity, economic development and a better life (Watch, 2010). This is in tandem with what Chareonwongsak (2008) asserted, that economic and national development is based on skilled manpower. In support of this, Patricia (2019) posited that graduate employability plays a key influence on economic growth. Although jobs require technical skills, nonetheless, generic skills are essential to success in today's work (Mohd. Noor, 2006). It is also paramount to ensure progressiveness in any career track (Rasul, Abdul Rauf \& Husain, 2014; Mokhtar, Rahman \& Husain, 2016).

Various terms are used to illustrate non-technical skills such as employability skills, necessary skills and key qualifications (Sodemann, 2008). The diversity of terms is situational and contextual. Sodemann (2008) defines employability skills as a soft skill required by young people who are ready to enter the realm of work. In Malaysia, these skills are also known as soft skills (Nik Ismail, 2010). It generally refers to a set of commendable personality and decent behaviours that enable a task to be executed smoothly 
and effectively, thus resulting in high productivity. Mohammad (2009) took into account the basic philosophy of national education when defining generic skills. His definition is holistic and based on fundamental religious principles which align with the context of generic skills in Malaysia.

Many studies on generic skills in various contexts and disciplines are available on electronic and printed media. This includes Ahmad, Jailani and Fadilah (2011) and Ghazalan, Ab Halim, Hamidon, Ahmad Hariri, Sallehuddin, Bahrol, Zakaria \& Roddin (2019) as well as studies on employability skills (Madar \& Buntat, 2011; Buntat, 2004; Saari \& Mat Rashid, 2013). The PhD of Mohd. Noor (2006) identified six essential generic skills for work, namely communication skills, interpersonal, teamwork, leadership, thinking skills and computer skills. Mohammad (2009) commented on the generic skills assessment system practised at University Kebangsaan Malaysia. Even more recently, Abdul Karim \& Maat (2019) developed a prediction model to anticipate the likelihood of attaining high-level employability skills among engineering technology students. These developments delineate the important of employability skills or generic skills among future-ready graduates who will enter the job market. In the same vein, Alias, Mohd Hamzah \& Yahya (2013) elucidated that beginning in 2005, many employers began to emphasise the importance of generic skills among university graduates. However, generic green skills in the context of environmental sustainability have been largely overlooked. According to a report issued by The Institute for Public Policy Research (2009), there are four types of skills that are considered to be lacking in green economy development and one of them is generic green skills.

\section{Green Evolution}

The concept of 'green' has begun to get extensive coverage and is becoming commonplace jargon among industry players, environmentalists, politicians, academics and researchers. This concept is nothing new and has existed since the sixties and seventies (Junus, 2009a). This development can be seen from several sequences of world events that lead to the emergence of green jobs and green skills.

The Montreal Protocol was enforced on January 1, 1989, enacted to protect the ozone layer by taking cautious measures in controlling emissions and releases of substances that may deplete the ozone layer. This Protocol was signed by 191 countries in September 1987. This was followed by the Rio Declaration (1992) on development and the environment or better known as the 'Earth Summit' which outlined 27 principles in sustainable development. Subsequent to it was the 'Kyoto Protocol' (1997). It was an international convention that established the obligations for industrialised nations to reduce the emission of greenhouse gases. The extension of the Kyoto Protocol is 'The Copenhagen Accord' (2010) which is geared towards addressing global climate change.

At the regional level, during the 33rd ASEAN Summit (ASEAN, 2018) held in Singapore, Heads of States/Governments launched 'The ASEAN Declaration on Promoting Green Jobs for Equity and Inclusive Growth of ASEAN Community', whereby, among other aims, it seeks a better understanding about green jobs and green skills in fostering green practices at the workplace. Meanwhile, The International Labour Organisation and United Nations Environment Programme (UNEP) defines green jobs as the direct employment in economic sectors and activities which reduce their negative environmental impacts, ultimately resulting in levels that are sustainable (ILO, 2014). It is clear that international initiatives are in tandem with regional endeavours to save the environment from becoming a victim in the name of development. Green jobs would only be a successful if employees adopt green practices, and to ensure this achievement, generic green skills are vital. Mustapha (2015) envisaged that green jobs have great potential in developing green economies.

At the national level, the 'Langkawi Declaration' (1989) on the environment and development of the Commonwealth countries aimed to ensure that development in British-colonised countries is developing in an environmentally friendly and sustainable framework. As a consequence of the declaration, October 21 was recognised as the 'National Environment Day'. It can be concluded that all the world events aimed to conserve the environment are in line with national development. In 2002, the National Policy on the Environment was launched (Ministry of Science, Technology and the Environment, Malaysia, 2002). It includes seven key areas of Malaysia's Green Strategies and one of them is directed towards education and awareness. The National Green Technology Policy (Ministry of Energy, Green Technology and Water, Malaysia, 2009) was launched in 2009, listing five objectives to be achieved, which embodies economic, environment and social policies.

One of the government's efforts to ensure environmental sustainability in line with the concept of sustainable development, is to add green technology within the Ministry of Energy, Green Technology and Water (KeTTHA). It works in planning, drafting green technology policies and programmes, leading the initiative to address current global issues such as environmental pollution, ozone layer depletion, global warming and related issues. This is followed by the launch of the National Green Technology Policy which encompasses four essences - energy, environment, economy and social wel-being - as well as the establishment of the Malaysian Government Industry Group for High Technology (MIGHT) which aimed to strengthen the development of the green technology industry.

These initiatives underscore the importance of keeping the environment, with regards to development, as natural as possible. An assortment of efforts were introduced involving various parties to guarantee the sustainability of the earth. Indirectly, these provide feedback on a criticism by the ILO Global Report (2011) in Pavlova (2014) which claimed that in many developing countries, governments have not yet responded to skill challenges associated with environmental issues and climate change. Pertaining to that, an African proverb which states 'we do not inherit the earth from our ancestors; we borrow it from our children' might be best to bear in our mind. 


\section{A. Green Technology Industry}

The green technology industry is an industrial cluster that uses environmentally- friendly equipment, machines and raw materials as well as caring for industrial waste management. From the perspective of the Ministry of Human Resource (2011), green technology refers to products, equipment or systems that meet the following criteria:

- able to minimise environmental degradation

- no or less emission of greenhouse gases

- save energy and natural resources

- encourage the use of renewable resources

In Malaysia, the green technology industry has great potential, not only in offering jobs but also business opportunities and green product-based services (Ministry of Human Resource, (2011). This is reinforced by the presence of the My Hijau Directory, which is regulated by the Malaysian Green Technology Corporation and promotes the use of eco-friendly products and services.

Referring to the Ministry of Human Resource (2011), the green technology industry and its related industries will be developed and transformed into a catalyst in supporting and contributing directly to economic growth. The Ministry of Human Resource (2011) also predicts improvements in the provision of competent manpower, especially in green technology that will be in line with industry needs. This indirectly creates more green jobs which also require generic green skills. Sern, Zaime \& Foong (2018) asserted that employers have already started eyeing human capital equipped with green skills needed to promote sustainable development in social, economic as well as environmental matters.

Apart from that, green technology also refers to environmentally-friendly technology. It has high efficiency value which at the moment is referred to as efficient and economical energy usage (Junus, 2009b). Although the focus of the development of green jobs in Malaysia is still at an early stage, nonetheless it does show promise. For example, efforts towards 'greening' technical skills that can sustain the environment in line with development have already begun. Among the initiatives is the issuance of a document entitled The Occupational Structure: The Green Technology Industry (Ministry of Human Resource, 2011) which complies with the Malaysian Occupational Skills Qualification Framework. The existence of green jobs indicates the emergence of 'green collar' workers. However, the question on what and how generic green skills could be inculcated in every green collar employee is still unanswered.

\section{B. Generic Green Skills}

For the purpose of writing this paper and taking into consideration an extensive and thorough review, the term 'generic green skills' is used interchangeably with green skills. Although technically green skills refer to combination of hard skill and soft skill of green jobs, generic green skills are seen as a stand-alone matter and complement hard skills. Even Pavlova (2014), in the framework of attitude change of a holistic approach in greening Vocational Training Providers, has separated the content (of teaching and learning) of generic green skills from the content of specific green skills. This coincides with what Kamis, Mustapha,
Abdul Wahab \& Ismail (2016) claimed that there is no accurate definition to describe the concept of green skills.

Internationally, many studies on generic green skills have been conducted. For instance, the Swinburne University of Technology through the Education for Sustainability Hub (2014) has listed nine generic green skills at the workplace, while Pavlova (2012) identified six aspects of generic green skills. At the local level, Mokhtar, Mokhtar, Mokhtar \& Mokhtar (2018) verified eleven generic green skills attribute that should be inculcated among polytechnic students, where these attributes correspond to the generic green skills suggested by ILO (2011).

Based on a meticulous review, it could be summarised that generic green skills are not a cutting-edge skill but value added elements of existing generic skills which take into account the sustainability of the environment for future survival. Brown (2012) named it as skills for sustainability, while Kamin, Hamza, Musta'amal \& Abd Hamid (2018) associated the cohesiveness of green skills, sustainability and sustainable development as 'the triplet concepts'. This coincides with the CEDEFOP (2010) report, where in low-carbon economic development, the counterbalance of generic skills, generic green skills and topping up skills related to existing jobs are more important than creating any specific green skills. In other words, these generic green skills can enrich employability skills for the purpose of expanding the prospects of job marketability as well as maintaining the quality of the environment.

A general understanding regarding the concept of generic skills is that it is more geared towards personal competence and interaction with others. It ignores the relationship with the environment. In contrast to generic skills, generic green skills do not only look at the relationship between individuals but also take into account the relationship and interaction with the environment. This is in tandem with Othman (2010), that human life is not limited to human relationships, but also human relationships with nature. Principally, the environment does not only refer to the flora and fauna ecosystem, it also includes community system and how these communities interact with the environment. This effort can be mobilised collectively, and if it is implemented properly, it may help to develop the economy while preserving environmental stability. This conforms to the concept of sustainable development where Meerah et al., (2005) conclude there are three components in the sustainable development concept, namely environment, society and economy where these three components are mutually dependent. Kamis, Alwi, Ismail, Zakaria \& Nur Yunus (2017) corroborated this aforementioned statement by stating that green skills which have a significant association with green technology will contribute to sustainable development in terms of the environment, economy and social activities. Abd Hamid, Kamin, Awang \& Hashim (2018) concluded that generic green skills are non-technical skills tailored to the need of a clean environment and are pertinent to green practices. 


\section{Education for Sustainable Development}

One thing to think about is how awareness of environmental sustainability can be rehearsed in the workplace by means of generic green skills practices. Among the mediums that can be used as a platform towards empowering sustainable practices in the workplace are through education and training. Through education, a large number of problems can be solved and at the same time education is able to provide a variety of opportunities (Watch, 2010). According to McKeown (2002), public awareness, education and training are key to leading the society to sustainability. This is corroborated by Ramli, Rasul \& Mohd Affandi (2018) that education plays major roles to develop skills for the green economy, up skilling 4th Industrial Revolution, social skills and environmental skills.

In the context of the Malaysian Educational System, the National Philosophy of Education is targeted at producing holistic and integrated students who are intellectually, spiritually, emotionally and physically balanced and harmonic. It is in accord with the major domains of human development which include social-emotional, physical, language and cognitive (Fraser-Thill, 2019). All these are intended to produce future human resource capable to socialise not only among colleagues and managerial and administrative staff, but most importantly developing holistic graduates who are able to preserve and conserve good quality of environment. Pavlova (2018) concluded that generic green skills has four competencies, namely cognitive, technological, interpersonal and intrapersonal competencies. These competencies are important to develop future holistic 'green collar' workforce who will get more offers in green jobs. As cited by Asnami \& Djatmiko (2015), jobs in various sectors of industry are now beginning to be oriented towards green jobs. Furthermore, these competencies of generic green skills are closely related to 21 st century skills, which there were clustered into four categories, namely ways of thinking (cognitive competencies), ways of working (interpersonal dan intrapersonal competencies), tools for working (technological competencies) and living in the world (Saavendra \& Opfer, 2012).

Unfortunately, despite the hard work of developing a green economy, Buntat, Othman, Saud, Mustaffa \& Syed Mansor (2013) found that many teachers do not understand green soft skills (generic green skills). While recognising that this generic green skill is indispensable in the green technology industry, its content, how it is implemented in the curriculum, its application and assessment methods, are still unknown (Buntat et al., 2013). In the same vein, Yusoff \& Surif (2013) found that the level of student knowledge of the concept of low-carbon society is still low.

Meanwhile, in the context of training and retraining, Pesek (2010) states that non-technical skills that are said to be 'green' in green training programmes should include teaching about green behaviour at work, green career planning and green skills which covers one-third of overall training programme. Deep understanding of the impact of employment-based development on the environment should be applied in the mainstream education and training system (CEDEFOP, 2010).

\section{CONCLUSION}

Research and referral resources on generic green skills and its relationship with sustainable development in Malaysia are still scarce. At the same time, by taking into account the rapid development of the national development agenda and environmental quality degradation, their needs are increasingly demanding. Generic green skills enhance the existing generic skills. For employees, every behaviour and job activities should reflect on the impact of their actions on the environment. Ultimately, those decent works will produce a 'green' phenomenon, and it might be used as a practical platform within the alignment of national development and environmental sustainability. Pertinent to that, generic green skills need to be practised in green technology industry so as to become a culture that contribute to a sustainable development. Therefore, more studies on generic green skills and its impact on sustainability are needed as a matter of urgency.

\section{ACKNOWLEDGMENT}

This research was funded by Fundamental Research Grant Scheme (FRGS), Ministry of Education Malaysia under vote number 4F841. Special thanks go to the Research Management Centre of Universiti Teknologi Malaysia for managing the activities of this research.

\section{REFERENCES}

1. Abd Hamid, M. Z., Kamin, Y., Awang, Z. \& Hashim, S. S., (2018) "Understanding of Generic Green Skills From the Perspective of Academics". paper presented at the $6^{\text {th }}$ ASEAN Human Resources Conference 2018, at Le Meridien Hotel, Kuala Lumpur. 27 Nov. 2018.

2. Abdul Karim, Z. I., \& Maat, S. M., (2019). Employability Skills Model for Engineering Technology Students. Journal of Technical Education and Training. Vol.11 (2), 079-087.

3. Ahmad, E., Jailani, M. Y. dan Fadilah M. A. (2011). The Implementation of Generic Skills at Technical Schools: Comparative analysis in different platform. Journal of Techno-Social,3 (2), pg. 23 - 41

4. Alias, R., Mohd Hamzah, M. I. \& Yahya, N., (2013). Generic Skill Requirements: Between Employer's Aspiration and the Need of Professional Employees. Jurnal Pengurusan, 37(2013), pg. 105 - 114.

5. ASEAN (2018). ASEAN Leaders Commit to Promote Green Jobs. https://asean.org/asean-leaders-commit-promote-green-jobs/ (Retrieved on 21 July 2019)

6. Asnami, R. \& Djatmiko, I. W. (2015). A Challenge of Vocational Education for Preparing Green Employment. The International Journal of Technical and Vocational Education (Invotec), Vol. XI (2), August, pg. 154-160.

7. Brown, M., (2012). Developing Green Skills Through TAFE Across Victoria. AVETRA, Canberra.

8. Buntat, Y., (2004). Integrasi Kemahiran Employability Dalam Program Pendidikan Vokasional Pertanian Dan Industri di Malaysia. Unpublished Ph.D thesis, University Teknologi Malaysia.

9. Buntat, Y., Othman, M., Saud, M. S., Mustaffa, M. S. \& Syed Mansor, S M. S., (2013). Integration of Green Soft Skills in Malaysian Technical Education. Advanced Science Letters, 19 (12), pg. 3718-3720.

10. CEDEFOP, (2010). Skills for Green Job: Developing a Low-Carbon Economy Depends on Improving Existing Skills Rather Than Specialised Green Skills. Briefing Note-9024 EN. Thessaloniki, Greece.

11. Chareonwongsak, K. (2008). Enhancing Graduate Employability: Shaping Thai Vocational Education to Enhance Thailand's Competitiveness. Asia Pacific Technical HRD Conference and Career Expo '08, 6 - 7 Ogos 2008, Kuching, Sarawak.

12. Fraser-Thill, R. (2019). Domains in Human Development. https://www.verywellfamily.com/definition-of-domain-3288323 (Retrieved $11^{\text {th }}$ July 2019) 
13. Ghazalan, M. S., Ab Halim, F., Hamidon, N. I., Ahmad Hariri, T. I. A., Sallehuddin, S. A., Bahrol, K., Zakaria, N. \& Roddin, R., (2019). Engineering Students' Generic Skills After Industrial Training: Employers' Perception. Journal of Technical Education and Training. Vol 11(2). pg. 058-067.

14. ILO (2011). Skills for Green Jobs: A Global View (Synthesis Report Based on 21 Country Studies). International Labor Organization, Geneva.

15. ILO (2014). Green Jobs Mapping Study in Malaysia. Bangkok: ILO Regional Office for Asia and the Pacific.

16. Junus, L. (2009a). Teknologi Hijau: Apa dan Kenapa? Estidotmy (edisi 20), Utusan Malaysia. Pg. 6-7.

17. Junus, L. (2009b). Pelancaran Dasar Teknologi Hijau Buka Lembaran Baru. Estidotmy (edisi 20), Utusan Malaysia pg. 4-5.

18. Kamin, Y., Hamza, S., Musta'amal, A. H. \& Abd Hamid, M. Z., (2018). "The Interconnectedness of the Concepts: Sustainability, Sustainable Development and Green Skills in the Paradigm of Building Technology Education". paper presented at the $6^{\text {th }}$ ASEAN Human Resources Conference 2018, at Le Meridien Hotel, Kuala Lumpur. 27 Nov. 2018.

19. Kamis, A., Alwi, A., Ismail, B. L., Zakaria, N. \& Nur Yunus, F. A., (2017). Integration of Green Skills in Sustainable Development in Technical and Vocational Education. International Journal of Engineering Research and Application. Vol. 7 (12), pg. 08-12.

20. Kamis, A., Mustapha, R., Abdul Wahab, N. \& Ismail, B. L., (2016). Green Skills as an Added-Value Element in Producing Competent Students. International Journal of Engineering Research and Application. Vol. 6 (11), pg. 12-21.

21. Madar, A. R., \& Buntat, Y., (2011). Elements of Employability Skills Among Students From Community Colleges Malaysia, Journal of Technical, Vocational \& Engineering Education, Vol. 4, pg. 1-11.

22. McKeown, R. (2002). The Education for Sustainable Toolkit. (http://www.esdtoolkit/org)

23. Meerah, S. M., Hanim, L., Othman, N. \& Aziz, Z., (2005). Pembangunan Lestari Melalui Pendidikan Guru. Prosiding Seminar Pendidikan JPPG2005, 28 - 30Ogos 2005. Hotel Shangri-La, Pulau Pinang. Pg. 8 13.

24. Ministry of Human Resource, (2011). Occupational Structure: Green Technology Industry, Jabatan Pembangunan Kemahiran, Bandar Baru Bangi, Selangor.

25. Ministry of Science, Technology and the Environment, Malaysia, (2002). National Policy on the Environment. Putrajaya: Ministry of Science, Technology and the Environment, Malaysia.

26. Ministry of Energy, Green Technology and Water, Malaysia. (2009). National Green Technology Policy. Putrajaya: Ministry of Energy, Green Technology and Water, Malaysia.

27. Mohammad, A. W., (2009). Sistem Penilaian Kemahiran Generik (SPKG): Pengalaman Daripada Perspektif Fakulti. Seminar Pendidikan Kejuruteraan Dan Alam Bina, Kongres Pengajaran dan Pembelajaran UKM. 209, pg. 25- 33

28. Mohd. Noor, N., (2006). Kepentingan Kemahiran Generik Untuk Pekerjaan Di Industri Dan Faktor Pembangunannya Dalam Pendidikan Vokasional Di Sekolah Menengah Teknik. Unpublished Ph.D thesis, University Teknologi Malaysia.

29. Mokhtar, S. B., Rahman, S. \& Husain, M. Y., (2016). Pemerkasaan Kemahiran Generik Pelajar. Bangi, Selangor: Penerbit Universiti Kebangsaan Malaysia.

30. Mokhtar, S. B., Mokhtar, S. I., Mokhtar, S. L. \& Mokhtar, S. W., (2018), Generic Green Skills Attributes and Delivery in Polytechnic Teaching and Learning Process. International Journal of Academic Research in Business \& Social Sciences. Vol. 8 (12), pg. 2013-2022.

31. Mustapha, R. B. (2015). Green and Sustainable Development for TVET in Asia. The International Journal of Technical and Vocational Education (Invotec), Vol. XI (2), August, pg. 133-142.

32. Nik Ismail, N. S., (2010). Soft Skills: The What, The Why, The How. Bangi, Selangor: Penerbit Universiti Kebangsaan Malaysia.

33. Nordin, A.B., (1994). Pendidikan: Menghadapi Cabaran Tahun 2020. In Reformasi Pendidikan Dalam Menghadapi Cabaran 2020. Kuala Lumpur: Nurin Enterprise. pg. 241-273.

34. Omardin, M. A. \& Zainul Abidin, N. (2014). Konsep Dan Amalan Kesedaran Terhadap Isu-isu Alam Sekitar Di Peringkat Awalan Projek Pembinaan Melalui Fasa Pengurusan Nilai. Social Sciences Postgraduate International Seminar (SSPIS, 2014). Dewan Persidangan Seminar, University Science Malaysia. 21 October 2014.

35. Othman, M. Y., (2010). Media Dan Isu Alam Sekitar, Jurnal Hadhari, 2 (2), pg. $1-17$.

36. Patricia, E.C. (2019). Generic Skills and Employability of TVET Graduates: The Role of Teachers in Nigeria. The International Journal of Vocational Education and Training. Vol. 25, Number 1, pg 43-51.

37. Pavlova, M. (2012). Generic Green Skills: Can They be Addressed Through Technology Education? Proceedings of the 7th Biennial
International Conference on Technology Education. 5 - 8 Dis. 2012.The Crowne Plaza Surfers Paradise, Australia, pg. 49 - 57.

38. Pavlova, M. (2014). Green Skills in Formal TVET: A Reflection on International Studies. WFCP World Congress 2014, incorporating China Annual Conference for International Education. China National Convention Center, Beijing. 24-26 October 2014.

39. Pavlova, M. (2018). Education 2030 and the Significance of $21^{\text {st }}$ Century Skills: Implications for TVET https://www.cna-qatar.com/research/DohaDeclaration/Documents/04.17. 2018\%20TVET\%202018\%20-

\%20Dr.\%20Margarita\%20Pavlova\%20Presentation.pdf (Retrieved $11^{\text {th }}$. July 2019)

40. Pesek, S. J., (2010). Training for Green Jobs. Federal Reserve Bank of Boston: Communities \& Banking, Spring. 21(2).

41. Rademaekers, K., Svatikova, K. \& Yearwood, J. (2015). Facilitating Green Skills And Jobs In Developing Countries. Technical Report N ${ }^{\circ} 9$ (2015). Paris, Agence Francaise \& Development.

42. Ramli, S., Rasul, M. S. \& Mohd Affandi, H., (2018). Sustainable Development: Needs of Green Skills in the Fourth Industrial Revolution (4IR). International Journal of Academic Research in Business \& Social Sciences. Vol. 8, No. 9, September, pg. 1082-1095.

43. Rasul, M. S., Abdul Rauf, R. A. \& Husain, M. Y., (2014). Kemahiran Kebolehdapatan Kerja: Suatu Keperluan Pekerjaan. Bangi, Selangor: Penerbit Universiti Kebangsaan Malaysia.

44. Ratnata, I. W. (2015). Efforts to Enhance the TVET Teachers Competencies Through Apprenticeship Approach Pattern in Industry. The International Journal of Technical and Vocational Education (Invotec), Vol. XI (2), August, pg. 124-132.

45. Saari, H. A., \& Mat Rashid, A., (2013). Competency Level of Employability Skills Among the Apprentices of the National Dual Training System: A Comparative Analysis of Industry Perception by Company Status. International Journal of Education and Research Vol. 1 (11)

46. Saavedra, A. R. \& Opfer, V. D. (2012). Teaching and Learning $21^{\text {st }}$ Century Skills: Lessons From the Learning Sciences. RAND Corporation: Asia Society Partnership for Global Learning.

47. Sern, L.C., Zaime, A. F. \& Foong, L.M., (2018). Green Skills for Green Industry: A Review of Literature. Journal of Physics:Conf.Series.1019. doi:10.1088/1742-6596/1019/1/012030

48. Sodemann, K. (2008). Soft Skills: Important in the World of Work and How to Train Them. Asia Pacific Technical HRD Conference and Career Expo '08, 6- 7 Ogos 2008, Kuching, Sarawak.

49. Swinburne University of Technology (2014). Green Skills, Green Jobs What's the Difference? www.swinburne.edu.au/ncs/efshub/greenskill.html (Retrieved 27 Jan. 2015)

50. Syarina Ramli, Mohamad Sattar Rasul \& Haryanti Mohd Affandi (2019) Challenges of Green Skills Development in Fourth Industrial Revolution (4IR). The International Journal of Vocational Education \& Training. Vol. 25, No. 1, pg. 52-63.

51. The Institute for Public Policy Research (2009). The Future's Green, Britain.

52. Watch, D. D. (2010). Research For the Global Good: Supporting a Better World For All.Victoria, Australia: The Images Publishing Group Pty Ltd.

53. Yusoff, S. \& Surif, J. (2013). Pengetahuan Dan Sikap Pelajar Terhadap Masyarakat Rendah Karbon Dalam Kurikulum Sains Sekolah Menengah. Buletin Persatuan Pendidikan Sains Dan Matematik Johor, 23(1), pg. 9 -21 .

\section{AUTHORS PROFILE}

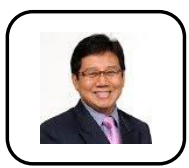

Dr. Mohd Zolkifli Abd Hamid is a senior lecturer attached to the Department of Technical and Engineering Education, School of Education, Faculty of Social Sciences and Humanities, University Teknologi Malaysia. He obtained his $\mathrm{PhD}$ degree in Technical and Vocational Education from University Teknologi Malaysia. He has written numerous papers for indexed journal and paperwork for conference. He actively engaged in research on Generic Green Skill. His major interest is on qualitative research methodology, instructional supervision and technical and vocational education. 
Dr. Mohd Safarin Nordin is currently working as Senior Lecturer in the Department of Technical and Engineering, School of Education, Faculty of Social Science and Humanities, Universiti Teknologi Malaysia. He completed his Phd Technical \& Vocational Education and Training from Universiti Teknologi Malaysia year 2009. He is actively involved in research on Visualization Skills, Instructional Design,and Problem-Project Based Learning in TVET. Currently he is Managing Editor for Journal of VOLT.

Assoc. Prof. Dr. Yusri Kamin is currently a Senior Lecturer and as a Head, Department of Technical and Engineering Education Department, Faculty of Education, Universiti Teknologi Malaysia. He obtained Bachelor of Technology with Education (Mechanical Engineering) and a Master of Education with Specialization in Technical and Vocational Education) from Universiti Teknologi Malaysia and $\mathrm{PhD}$ (Technical and Vocational Education) from La Trobe University, Melbourne, Australia Among the positions that he held were Head of Department Technical and Vocational and Academic Manager for External Program.

Assoc. Prof. Dr. Aede Hatib Musta'amal is an Associate Professor at Department of Technical and Engineering Education, School of Education, Faculty of Social Sciences and Humanities. He teaches a number of courses for Technical and Engineering Education Program at Undergraduate and Postgraduate level. He is involving a number of research study, and research supervision in Technic and Vocational Education context including Creativity and Innovation, Green Skills, Competency Measurement, and others. 